\title{
TRONDHEIM NATURAL RADIOCARBON MEASUREMENTS II
}

\author{
R. NYDAL \\ Radiological Dating Laboratory \\ The Norwegian Institute of Technology, Trondheim, Norway

\section{INTRODUCTION}

This date list covers the period from September 1958 to December 1959 and a few earlier dates omitted from our first list (Nydal, 1959). As regards the geologic samples, the accordance between the $\mathrm{C}^{14}$ age and the age predicted from geologic considerations is generally very good, and most of the discrepancies can be reconciled in favor of the $\mathrm{C}^{14}$ result.

Particularly serious are some deviations that arise with samples of wellknown archaeologic age. This is especially the case with charcoal from certain habitation sites, where the discrepancies exceed any possible systematic error (T-134 and T-136). The explanation of such discrepancies has been rather difficult.

Counter design.-Our laboratory has now two different counter designs and two electronic counting units for $\mathrm{C}^{14}$ measurement.

Counter 1, described earlier (Trondheim I, 1959), has been used since we started with $\mathrm{CO}_{2}$ gas-counting in 1956. It is a proportional counter of stainless steel, with total volume of 6.3 liters. The effective volume was only about $40 \%$ of total volume, because of the grid construction. Although this grid had some advantages (Nydal and Sigmond, 1957), the large dead volume was a great drawback. Therefore the grid was removed and the counter modified in some ways. The new counter data may be summarized as follows: The total voltage is now applied to the counter wall which serves as cathode. The center wire of stainless steel, $0.1 \mathrm{~mm}$, is insulated from the end plates with Teflon insulators. In order to remove the large end effect in a counter with such a large diameter $(13 \mathrm{~cm})$, field tubes (Cockroft and Curran, 1951) are mounted at the ends of the insulators. The field tubes are given a potential just high enough to remove the end effect. The effective volume of the counter is now about $75 \%$ of total volume. The counter is normally operated at 2 atmospheres $\mathrm{CO}_{2}$; at this pressure the background is 12.5 counts/min and the $\mathrm{C}^{14}$ net count of recent wood is 62.0 counts $/ \mathrm{min}$. Anticoincidence shielding is provided by a multiple-anode anticoincidence ring counter (Reath, Sevold, and Pederson, 1951) consisting of 16 contiguous counter sections. It is filled with propane at 1.5 atmospheres pressure. The ring counter is in electric contact with the proportional counter, and both counters are adjusted to the same working voltage $(7.75 \mathrm{kV})$. The whole system operates in the proportional region and is insulated from the iron shield ( $22 \mathrm{~cm}$ thickness) by a perspex plate. Counter 1 is now used for special purposes only, being very useful for dates between 30,000 and 45,000 years. Samples T-146 and T-160 have been dated in this counter; other samples dated since September 1958 have been measured in Counter 2. 
Counter 2 was designed to measure the many young samples $(<13,000$ yr) received in our laboratory. It is made of commercial copper and has a total volume of 1.5 liters, the effective volume being about $80 \%$ of the total. The center wire is $0.1 \mathrm{~mm}$ thick and is insulated from the end plates by Pyrex insulators. The counter is normally operated at 2 atmospheres $\mathrm{CO}_{2}$. Higher pressures give no advantage, because the counter is more sensitive to electronegative impurities with rising pressure. The background is 8.5 counts $/ \mathrm{min}$, and the net count of recent carbon 16.5 counts $/ \mathrm{min}$. The counter is shielded by 13 glass Geiger-Müller tubes in anticoincidence, and further protected inside an iron chamber of $22 \mathrm{~cm}$ thickness. The counter is capable of dating samples up to 30,000 years. For very small samples with 1.5 liters of $\mathrm{CO}_{2}$ or less (T-143, T-148, T-110, and T-113), the pressure in the counter was lowered to 1 atmosphere.

Pretreatment.-We have largely followed the purification procedure developed at the $\mathrm{C}^{14}$ laboratory in Groningen. The pretreatment described in Trondheim I $(0.25 \mathrm{M} \mathrm{HCl}$ and $0.25 \mathrm{M} \mathrm{NaOH})$ was practiced until February 1959. The reagents seemed then to be a little too weak in certain cases, and stronger $\mathrm{NaOH}$ and $\mathrm{HCl}$ (about $\mathrm{l} \mathrm{M}$ each) was introduced for all kinds of organic samples, even peat and gyttja. Shell samples are generally washed and treated with $1 \mathrm{M} \mathrm{HCl}$ for $2 \mathrm{~min}$, and then a surface layer, amounting from 5 to $20 \%$ of the total weight, is removed. Deviation from the pretreatments described here are pointed out in the text.

Calculation.-As in Trondheim I (Nydal, 1959), the age of the dated samples are all given in the B.P. scale. The statistical error $(\sigma)$ given for each dating is the standard deviation calculated from the counting statistics. The calculated $\sigma$ is in accordance with the observed deviations of shorter counts. The lower limit of age of "infinitely" old samples is calculated with an accuracy of about $95 \%(2 \sigma)$.

The dates are not corrected for barometric pressure, as this correction would be negligible in comparison to the statistical error. The variation in background with barometric pressure is about $0.5 \% / \mathrm{cm} \mathrm{Hg}$.

The radon content is checked for each dating. The measurements are carried out with such a low radon content that no correction has been necessary. The $\mathrm{C}^{14}$ half-life used here is 5570 years; its standard deviation \pm 30 years, is not included in the standard deviation of the dating results.

Standard samples.-Our recent standard (T-60) has until December 1959 been a 50-year-old wood sample (Populus balsamifera) from the outskirts of Trondheim $\left(63^{\circ} 11^{\prime} \mathrm{N}\right.$ Lat, $10^{\circ} 24^{\prime} \mathrm{E}$ Long), Norway. This standard has now been checked against a standard of oxalic acid (T-200) from the U. S. National Bureau of Standards and further against a standard sample from Heidelberg (T-201). The comparison is expressed as $\delta \mathrm{C}^{14}$ in per mil deviation from our recent wood standard:

$$
\begin{aligned}
& \delta \mathrm{C}^{14}=\left(\frac{\mathrm{A}_{\mathrm{ox}}-\mathrm{A}_{\mathrm{st}}}{\mathrm{A}_{\mathrm{st}}}\right) \times 1000=64 \pm 6 \% 0 \\
& \delta \mathrm{C}^{14}=\left(\frac{\mathrm{A}_{\mathrm{H}}-\mathrm{A}_{\mathrm{st}}}{\mathrm{A}_{\mathrm{st}}}\right) \times 1000=37 \pm 6 \% 0
\end{aligned}
$$


$A_{o x}=$ the measured activity of the NBS standard.

$A_{H}=$ one-tenth of the activity of the enriched Heidelberg standard.

$A_{\text {st }}=$ the activity of the Trondheim recent wood standard corrected for age.

The recent standard T-60 shows a normal deviation from the two other standards. This conclusion is based on information given at the $\mathrm{C}^{14}$ conference in Groningen 1959. The members of the conference have agreed to use $95 \%$ of the activity of the NBS standard as a normal recent wood activity at the year 1950 A.D. This activity shows a deviation of only $10 \pm 6 \%$ from T-60, and therefore no age correction seems necessary for the dates already measured on organic samples.

Our modern shell standard (T-199, Mytilus edulis) was collected in 1957 A.D. just below sealevel at low tide in the Trondheimsfjord, near Trondheim $\left(63^{\circ} 27^{\prime} \mathrm{N}\right.$ Lat, $10^{\circ} 18^{\prime} \mathrm{E}$ Long). This sample gives within the limit of error the same activity as $95 \%$ of the NBS standard. The accordance is due to the fact that the specific $\mathrm{C}^{14}$ activity in the shells has been depleted by $5 \%$, which corresponds to an apparent age of 400 years for the bicarbonate in the surface water of the ocean (Craig, 1954). The age of the dated shell samples should therefore be correct within the limit of error.

Fractionation analysis of $C^{13} / C^{12}$. - The standard samples were all sent to Stockholm for $\mathrm{C}^{13} / \mathrm{C}^{12}$ analysis. As a standard for these measurements, our laboratory has arbitrarily chosen a sample of stromatolitic limestone (T-146). The deviation from this standard is denoted by $\delta \mathrm{C}^{13}$ and is expressed in per mil (Craig, 1954). The limit of error in $\delta$ is $\pm 1.0 \%$.

$$
\begin{aligned}
& \delta \mathrm{C}^{13}=\left(\frac{\mathrm{C}^{13} / \mathrm{C}^{12} \text { sample }-\mathrm{C}^{13} / \mathrm{C}^{12} \text { standard }}{\mathrm{C}^{13} / \mathrm{C}^{12} \text { standard }}\right) \times 1000 \\
& \text { Sample }
\end{aligned}
$$

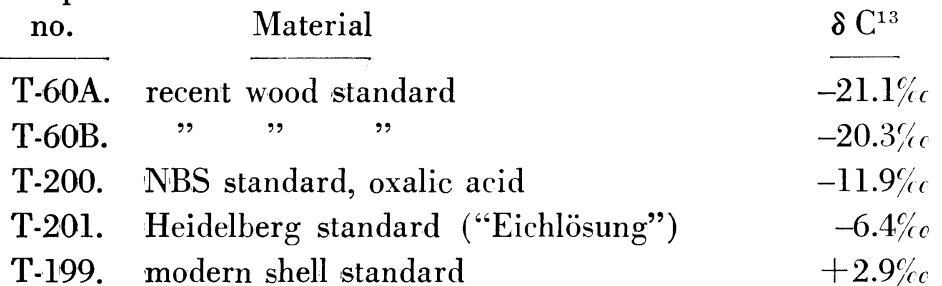

Besides these $\mathrm{C}^{13} / \mathrm{C}^{12}$ measurements, only six dated samples (T-119C, T-141, T-149B, T-150, T-151 and T-164) are mass-spectroscopically analyzed. A portion of $\mathrm{CO}_{2}$ from sample $\mathrm{T}-200$ will be analyzed for $\mathrm{C}^{13}$ at the Lamont laboratory. This measurement will give us the factor needed for conversion to Craig's scale (Craig, 1953).

\section{ACKNOWLEDGMENTS}

The author wants to express his deep gratitude for information, comments, and corrections given by all those who have collected and submitted the samples; to Dr. R. Ryhage, Karolinska Institutet, Stockholm, for his kindness 
in making the $\mathrm{C}^{13} / \mathrm{C}^{12}$ determination; and to Professor Dr. S. Westin, the supervisor of the laboratory.

I am particularly grateful to the laboratory staff, C. M. Jörgensen, N. Holme, and A. L. Johansen for treating and counting samples and statistical calculation of counting results. Financial support from Norges Almenvitenskapelige Forskningsråd is gratefully acknowledged.

\section{SAMPLE DESCRIPTIONS \\ I. GEOLOGIC SAMPLES \\ Norway \\ 1. The Tromsö Glacial Substage}

\section{T-51. Prestvann, Troms}

$11,680 \pm 170$

Dy and gyttja from the lowest $5 \mathrm{~cm}$ of a bog, $5 \mathrm{~m}$ deep, in a kettle on the Tromsö end moraine at Prestvann near the town Tromsö, Troms $\left(69^{\circ} 40^{\prime} \mathrm{N}\right.$ Lat, 18 ${ }^{\circ} 58^{\prime}$ E Long), Norway. Coll. 1957 and subm. by B. G. Andersen, University of Oslo. Comment: dated in 1957. Pretreatment: $0.25 \mathrm{M} \mathrm{HCl}$ only. (B.G.A.) : kettle lies in the oldest part of the Tromsö end moraines, and the sample gives a minimum date for the end moraine.

\section{T-110. Breivikeid terrace, Troms $\quad 11,500 \pm 400$}

Shells of Portlandia arctica and Macoma calcarea from a laminated clay in a raised marine delta built of outwash at Stormo in Breivikeid between Ulsfjord and Balsfjord in Troms (69 $35^{\circ} \mathrm{N}$ Lat, $19^{\circ} 24^{\prime} \mathrm{E}$ Long), Norway. The clay lies about $56 \mathrm{~m}$ above sealevel and is overlain by $4 \mathrm{~m}$ of bedded sand and gravel. Coll. 1958 and subm. by B. G. Andersen, University of Oslo. Comment (B.G.A.) : as the outwash terrace is ca. $60 \mathrm{~m}$ above sealevel at Stormo and rises gradually toward and is correlated with the end moraine of the Tromsö glacial substage, the shells probably date that moraine.

\section{T-112. Langnes, Troms}

Shells of Pecten islandicus, Mya truncata, and other genera from glaciomarine gravel beds in an end-moraine ridge of the Tromsö glacial substage at Langnes near Tromsö, Troms ( $69^{\circ} 40^{\prime} \mathrm{N}$ Lat, $18^{\circ} 58^{\prime} \mathrm{E}$ Long), Norway. The glaciomarine beds, locally contorted, lie 6 to $10 \mathrm{~m}$ above sealevel and are overlain by a bed of bouldery till, 2 to $3 \mathrm{~m}$ thick. Coll. 1958 and subm. by B. G. Andersen, University of Oslo. Comment (B.G.A.) : the shells probably date the Tromsö glacial substage and are definitely older than the youngest part of this substage.

\section{T-113. Tromsdal, Troms}

Shells of Arca glacialis, Mytilus edulis, and other genera from clay at the mouth of the Tromsdal Valley near Tromsö, Troms $\left(69^{\circ} 40^{\prime} \mathrm{N}\right.$ Lat, $19^{\circ} 0^{\prime} \mathrm{E}$ Long), Norway. The clay lies ca. $10 \mathrm{~m}$ above sealevel and 100 to $200 \mathrm{~m}$ outside the Tromsö end moraine. It is overlain by a layer of sandy clay with postglacial shells. Coll. 1958 and subm. by B. G. Andersen, University of Oslo. Comment (B.G.A.) : the shells are believed to be younger than or contemporaneous with the Tromsö substage. 
T-111. Renså, Troms

Shells of Pecten islandicus, Arctica (Cyprina) islandica, and other genera from glaciomarine beds of sand and gravel in an end-moraine ridge that dams the Renså Lake near Harstad, Troms (68 $40^{\prime} \mathrm{N}$ Lat, $16^{\circ} 55^{\prime}$ E Long), Norway. Coll. 1958 and subm. by B. G. Andersen, University of Oslo. Comment (B.G.A.) : as the moraine is correlated with the Tromsö moraines, the shells probably date those moraines. The age of a moraine at Bjorelv (T-50) and the minimum age of a moraine near Bröstad (T-53) in Troms are respectively $10,500 \pm 400$ and $10,720 \pm 240 \mathrm{yr}$ (Nydal, 1959). Both moraines are correlated with the Tromsö moraines. All the dates mentioned (T-50, T-51, T-53, T-110, T-111, T-112, T-113) seem to fix the age of the Tromsö glacial substage between 10,500 and $11,700 \mathrm{yr}$.

T-124. Steinsdal, Helgeland

$10,300 \pm 250$

Shells of Portlandia arctica from Steinsdal, Sömna, Helgeland $\left(65^{\circ} 17^{\prime}\right.$

$\mathrm{N}$ Lat, $12^{\circ} 09^{\prime} \mathrm{E}$ Long), Norway. From Yoldia clay, 8 to $10 \mathrm{~m}$ above sealevel, at a locality ca. $8 \mathrm{~km}$ in front of a terminal moraine probably belonging to the Tromsö-Lyngen substage, respectively the Ra-substage. Local glaciers may have existed nearer to the locality. Coll. 1958 by Marius Marthinussen; subm. 1958 by Olaf Holtedahl, Department of Geology, University of Oslo. Comment: expected date: ca. 10,500 yr.

\section{T-125. Birtavarre, Troms}

$9880 \pm \mathbf{2 4 0}$

Shells of Mya truncata from Birtavarre, Lyngen, Troms $\left(69^{\circ} 36^{\prime}\right.$ N Lat, $20^{\circ} 53^{\prime} \mathrm{E}$ Long), Norway. Found at altitude $45 \mathrm{~m}$ in the face of a terrace $88 \mathrm{~m}$ high. Coll. 1957 by R. W. Feyling-Hanssen, Geological Survey of Norway; subm. 1958 by Olaf Holtedahl, University of Oslo. Comment (R.W.F.-H.) : the shells were imbedded in the sediment at a time when the shoreline was situated $88 \mathrm{~m}$ above that of the present day. This level represents also the marine limit for the locality.

T-126. Oldervik, Finmark

$4820 \pm 160$

Driftwood of Picea sp. from Oldervik, Seiland, Finmark $\left(70^{\circ} 17^{\prime}\right.$ N Lat, $23^{\circ} 06^{\prime}$ E Long), Norway. Found at the base of bog peat, $15 \mathrm{~m}$ above sealevel corresponding to a shore level of early Sub-Boreal time ("the youngest Tapes level", T IV in the system of Marthinussen, 1945). Coll. 1938 by Marius Marthinussen; subm. 1958 by Olaf Holtedahl, University of Oslo. Comment: expected date: ca. $4600 \mathrm{yr}$.

\section{Marine Clay and Shorelines in the Oslo Region}

\section{T-118. Foss Teglverk, Oslo}

$9850 \pm 350$

Shells, most Arca glacialis, from Övre Foss Teglverk, Oslo (59 $56^{\prime} \mathrm{N}$ Lat, $10^{\circ} 46^{\prime} \mathrm{E}$ Long), Norway. Found 15 to $18 \mathrm{~m}$ above sealevel in younger Arca clay deposited in front of moraine of the Aker stage (Brögger, 1901, p. 156-164). Coll. about 1860 by Michael Sars; subm. 1958 by Olaf Holtedahl, University of Oslo. Comment: expected date: ca. 10,000 yr.

\section{Skådalen series, Oslo}

Shells from Skådalen near Oslo $\left(59^{\circ} 58^{\prime} \mathrm{N}\right.$ Lat, $10^{\circ} 4 \mathrm{l}^{\prime} \mathrm{E}$ Long), Nor- 
way. Found in gravel $221 \mathrm{~m}$ above sealevel at the marine limit. T-119A coll. 1936 by H. Rosendahl, T-119B, and C coll. 1909 by P. A. Öyen, University of Oslo; subm. 1958 by Olaf Holtedahl, University of Oslo.
T-119A. Skådalen, Mytilus edulis
$9250 \pm 250$
T-119B. Skådalen, Balanus porcatus
$7300 \pm 200$
T-119C. Skådalen, Mytilus edulis
$9450 \pm 250$

Comment: expected date: 9500 yr. T-119B shows a larger deviation from T-119A and $\mathrm{C}$ than predicted by statistics. The discrepancy is therefore diffcult to explain except as contamination. The most reasonable age in the present case is $9350 \pm 200 \mathrm{yr}$ calculated from T-119A and C only.

\section{T-120. Havnens Teglverk, Oslo}

$9100 \pm 180$

Shells of Arctica (Cyprina) islandica from Havnens Teglverk, Oslo $\left(59^{\circ}\right.$ $56^{\prime} \mathrm{N}$ Lat, $10^{\circ} 46^{\prime} \mathrm{E}$ Long), Norway. Found at Akerselva in the oldest Cardium clay ca. $100 \mathrm{~m}$ above sealevel (Brögger, 1901, p. 286 ff.). Coll. 1899 by W. C. Brögger, University of Oslo; subm. 1959 by Olaf Holtedahl, University of Oslo. Comment (O.H.) : implies a more rapid amelioration of the climate than previously assumed by Brögger.

\section{T-122. City of Oslo}

$660 \pm 100$

Shells of Scrobicularia piperata and Mytilus edulis from the SE part of Oslo ( $59^{\circ} 56^{\prime} \mathrm{N}$ Lat, $10^{\circ} 46^{\prime}$ E Long), Norway. Found in Scrobicularia clay between Bekkegata and Lakkegata at a depth of between 2 to $3 \mathrm{~m}$, thus very near present sealevel. Coll. about 1900 by W. C. Brögger, University of Oslo; subm. 1958 by Olaf Holtedahl, University of Oslo. Comment (O.H.) : if right, the figure gives interesting indications concerning the extension of the town of Oslo in the Middle Ages. A muddy shallow sea must have existed in this district.

\section{T-117. Valle Teglverk, Fredrikstad}

$9950 \pm 300$

Shells of Portlandia arctica from Valle Teglverk, Fredrikstad $\left(59^{\circ} 15^{\prime} \mathrm{N}\right.$ Lat, $10^{\circ} 58^{\prime} \mathrm{E}$ Long), Norway. Found in Yoldia clay in front of the Ra moraine 10 to $15 \mathrm{~m}$ above sealevel (Brögger, 1901, p. $22 \mathrm{ff}$ ). Coll. 1900 by W. C. Brögger and others, University of Oslo; subm. 1958 by Olaf Holtedahl, University of Oslo. Comment: expected date: ca. 10,500 yr. This agrees with the $\mathrm{C}^{14}$ age within $2 \sigma$.

\section{T-121. Valle Teglverk, Fredrikstad}

$6570 \pm 150$

Shells of Isocardia cor from Valle Teglverk, Fredrikstad $\left(59^{\circ} 15^{\prime} \mathrm{N}\right.$ Lat, $10^{\circ} 58^{\prime} \mathrm{E}$ Long), Norway. Found in Isocardia clay ca. $20 \mathrm{~m}$ above sealevel (Brögger 1901, p. 487 ff.). Coll. 1899 by W. C. Brögger and P. A. Öyen, University of Oslo; subm. 1958 by Olaf Holtedahl, University of Oslo. Comment: expected date: 6000 to $7000 \mathrm{yr}$.

\section{T-123. Breif jell, Fredrikstad}

$6850 \pm .170$

Shells of Littorina littorea from Breifjell, Kråkeröy, Fredrikstad $\left(59^{\circ} 10^{\prime}\right.$ $\mathrm{N}$ Lat, $10^{\circ} 54^{\prime} \mathrm{E}$ Long), Norway. Found $50 \mathrm{~m}$ above sealevel, the shells date the corresponding sealevel. Coll. 1958 by E. Johansen, University Museum of 
National Antiquities, Oslo; subm. 1958 by Olaf Holtedahl, University of Oslo. Comment: expected date: 6000 to $7000 \mathrm{yr}$.

\section{Holtantjern series, Vestfold}

Gyttja from a bog, close to the lake Holtantjern, Tjölling, Vestfold $\left(59^{\circ}\right.$

$17^{\prime} \mathrm{N}$ Lat, $10^{\circ} 28^{\prime} \mathrm{E}$ Long), Norway. Altitude of lake surface is ca. $11.5 \mathrm{~m}$; samples were collected (at different times) from a depth of 3.02 to $3.15 \mathrm{~m}$, just above marine sediments. T-89A was collected by a Hiller borer, and T-89B by a piston borer $4 \mathrm{~cm}$ in diam. Coll. 1957 and subm. by Kari Egede Larssen, Geological Survey of Norway, Oslo.

\section{T-89A. Holtanjern, Hiller sample}

T-89B. Holtantjern, piston sample

$$
\begin{aligned}
& 2100 \pm 130 \\
& 2400 \pm 150
\end{aligned}
$$

Comment: dated 1957. Pretreatment: $0.25 \mathrm{M} \mathrm{HCl}$ only. (K.E.L.) : Pollenanalytic dating: just below the beginning of the Picea curve. Samples T-89A and $\mathrm{B}$ belong to the same series as samples T-87, T-88, T-90 (Trondheim I). The $\mathrm{C}^{14}$ age is younger than earlier assumed for the beginning of the Picea curve in this area. A similar relationship exists in the SW part of Sweden (Lundqvist, 1957).

\section{Linnom series, Vestfold}

Gyttja from a bog at Linnom, Slagen, Vestfold $\left(59^{\circ} 17^{\prime} \mathrm{N}\right.$ Lat, $10^{\circ} 28^{\prime}$ E Long), Norway. Altitude $26.5 \mathrm{~m}$ above sealevel; samples were collected (at different times) from a depth of 4.72 to $4.85 \mathrm{~m}$, just above marine sediments. T-91A was collected by a Hiller borer and T-91B by a piston borer, $4 \mathrm{~cm}$ in diam. Coll. 1957 and subm. by Kari Egede Larssen, Geological Survey of Norway, Oslo.

\section{T-91A. Linnom, Hiller sample $\quad 3700 \pm 150$ \\ T-91B. Linnom, piston sample $\quad 3100 \pm 120$}

Comment (K.E.L.) : pollen-analytic dating: Sub-Boreal time. The $\mathrm{C}^{14}$ dating of T-91A was carried out in 1957, and both samples belong to the same series as T-87, T-88, and T-90. The submitter has given her comment under T-90 (Trondheim I).

\section{Geologic Samples from Western and Southern Coasts of Norway}

\section{Blomvåg series, near Bergen}

Wood (T-138) and shells of Mytilus edulis (T-139) from Blomvåg, Blomöy, Hordaland $\left(60^{\circ} 31^{\prime} \mathrm{N}\right.$ Lat, $4^{\circ} 52^{\prime} \mathrm{E}$ Long), Norway. From fossilbearing gravel below layers of mud and till, $12 \mathrm{~m}$ above sealevel (Undås, 1942). T-138 coll. 1941 by A. Monsen, Geological Institute, Bergen. T-139 coll. 1942 by Isak Undås, Bergen. Subm. 1959 by Hans Holtedahl, University of Bergen.

T-138. Blomvåg, wood

$$
12,200 \pm 350
$$

T-139. Blomvåg, Mytilus edulis shells

$$
12,700 \pm 350
$$

Comment (H.H.) : the assumed interglacial age of the fossils must, according to the $\mathrm{C}^{14}$ result, be incorrect. The calculated age corresponds to the Older Dryas phase, and the till above the fossil-bearing horizon may have been deposited during that time, or possibly during the Younger Dryas phase. 
T-140. Bö Teglverk, Karmöy

$34,000 \pm 3000$

Shells of My truncata from shelly till, Bö Teglverk, Karmöy, Hordaland, (59 $9^{\circ} 23^{\prime} \mathrm{N}$ Lat, $5^{\circ} 17^{\prime} \mathrm{E}$ Long), Norway. Coll. 1905 by F. Övrebö, Bergen and 1958 by Hans Holtedahl, University of Bergen; subm. 1958 by Holtedahl. The shells collected in 1958 were found $4 \mathrm{~m}$ below the surface at altitude ca. $7 \mathrm{~m}$ above sealevel. The precise position of the shells collected in 1905 was not specified by the collector. Owing to the homogenous structure of the till, the total shell material was mixed together in order to provide enough $\mathrm{CO}_{2}$ gas for the counter. Comment (H.H.): the age of the shell fragments imbedded in the till is not late-glacial as earlier assumed, but probably interstadial. The till was deposited by a glacier which moved in a westerly direction (Öyen, 1905; Kolderup, 1908; Horn and Isachsen, 1942).

T-141. Hardangerf jord, bottom core

$\mathbf{5 2 5 0} \pm \mathbf{1 5 0}$

Shells of Lima excavata and other genera from Kvinnheradfjord, Hardangerfjord $\left(60^{\circ} 0^{\prime} \mathrm{N}\right.$ Lat, $5^{\circ} 54^{\prime} \mathrm{E}$ Long), Norway. From a bottom core, $1.5 \mathrm{~m}$ below the bottom surface at a depth of $660 \mathrm{~m}$. Coll. 1958 and subm. by Hans Holtedahl, University of Bergen. Comment (H.H.) : date of shells suggests Atlantic time, and sedimentation of the upper $1.5 \mathrm{~m}$ of the core has taken place at an average rate of $0.3 \mathrm{~mm} / \mathrm{yr}$.

T-142. Ulvenvann, Bergen

$11,500 \pm 300$

Shells of Mya truncata in a brook from Ulvenvann, Os, near Bergen $\left(60^{\circ}\right.$ $11^{\prime} \mathrm{N}$ Lat, $5^{\circ} 27^{\prime} \mathrm{E}$ Long), Norway. Found in till, altitude ca. $40 \mathrm{~m}$ above sealevel at depth of $2 \mathrm{~m}$. Coll. 1958 by Isak Undås, Bergen; subm. 1959 by Hans Holtedahl, University of Bergen. Comment (H.H.) : as the $\mathrm{C}^{14}$ date indicates an Alleröd age for the shell material, the inclosing till must be of Younger Dryas age. The Ra-stage moraines must therefore be situated to the west of the Os area (Kolderup, 1908).

T-143. Norwegian Sea, bottom core

Calcareous mud from the Norwegian Sea, E of Iceland $\left(65^{\circ} 20^{\prime} \mathrm{N}\right.$ Lat, $7^{\circ} 11^{\prime} \mathrm{E}$ Long). Coll. in a bottom core, 70 to $90 \mathrm{~cm}$ below the bottom surface, at depth of $2000 \mathrm{~m}$. Coll. 1954 and subm. 1959 by Hans Holtedahl, University of Bergen. Comment: no pretreatment with HCl. (H.H.) : sample belongs to a deposit of supposedly mild climatic period between two colder, the latter indicated by erratics denoting iceberg rafting. The calcareous mud has been deposited in a period prior to the Late-glacial climatic amelioration (Holtedahl, 1956, p. 138-160).

T-148. Lura, Sandnes

Shell fragments of Portlandia arctica from Yoldia clay found near the railway at Lura, Sandnes, Rogaland ( $58^{\circ} 52^{\prime} \mathrm{N}$ Lat, $4^{\circ} 58^{\prime} \mathrm{E}$ Long), Norway. The clay is strongly compacted, probably by glacier ice and primary overlying sediments. Sample collected from an especially shell-rich layer at a depth of 2 to $5 \mathrm{~m}$ by means of several borings. Coll. and subm. by R. Selmer-Olsen, The Norwegian Institute of Technology, Trondheim. Comment: no pretreatment with HCl. (R.S.-0.) expected age: 20,000 to 30,000 yr, last part of the 
last interstadial. The stratigraphy suggests readvance of the glacier after the deposition of the shells.

T-116. Tvihaugsbekken, Jaeren

Shell fragments of Arctica (Cyprina) islandica, from Tvihaugsbekken, Jaeren, Rogaland $\left(58^{\circ} 37^{\prime} \mathrm{N}\right.$ Lat, $5^{\circ} 58^{\prime} \mathrm{E}$ Long), Norway. Imbedded in till at altitude 5 to $20 \mathrm{~m}$ above sealevel (Björlykke, 1908). Coll. 1907 by K. O. Björlykke, Agricultural University, Ås, near Oslo; subm. 1958 by Olaf Holtedahl, University of Oslo. Comment (O.H.) : as the inclosing till had been generally supposed to date from the glaciation before the last one (the "Skagerak glaciation"), the result agrees with expectation.

\section{Primstad series, Jaeren}

Humus from a section of Alleröd soil at Primstad, Jaeren, Rogaland $\left(58^{\circ}\right.$ $40^{\prime} \mathrm{N}$ Lat, $5^{\circ} 3^{\prime} \mathrm{E}$ Long), Norway. Thin (about $20 \mathrm{~cm}$ ), contorted humus layers in till-like material. Most probably the same layer in both samples in spite of different stratigraphic position. The soil was buried by solifluction, presumably during Younger Dryas Age. Coll. and subm. by Knut Faegri and Ulf Hafsten, University of Bergen.

\section{T-105. Primstad, lower layer $\quad 11,700 \pm 300$ \\ T-106. Primstad, upper layer $\quad 11,600 \pm 300$}

Comment: pretreatment: $0.25 \mathrm{M} \mathrm{HCl}$ only. A sample (T-27) of the same soil section was $\mathrm{C}^{14}$ dated in 1956 (unpublished) to determine whether the humus is of interglacial or postglacial origin. The sample turned out to be postglacial (T-27: 10,900 $\pm 360 \mathrm{yr}$ ). Coll. and subm. by G. Semb, Agricultural University, Ås, near Oslo. The date was found so important that a check was considered desirable (T-105 and T-106). Pollen-analytical analysis of T-27 by Knut Faegri: Pinus 14\%, Betula 11\%, Salix 8\%, Cyperaceae 56\%, Granineae $5 \%$, Ericaceae $6 \%$.

\section{Bröndmyra series, Jaeren}

The dates represent the deposits of Bröndmyra, Jaeren, Rogaland $\left(58^{\circ}\right.$ $48^{\prime} \mathrm{N}$ Lat, $5^{\circ} 5^{\prime} \mathrm{E}$ Long), Norway. Bröndmyra, which has been repeatedly described (Faegri, 1936, pl. II; 1940, pl. IV; cf. also Faegri, 1953; Holmboe, 1903), is a peat bog, 14 m above sealevel, situated in a small, isolated depression. Clayey moraine lies underneath at $116 \mathrm{~cm}$ depth; the bog surface is cultivated. The following samples were collected from various depths. Coll. 1958 and subm. by Knut Faegri, University of Bergen.

T-149A. Gyttja with rootlets $\quad 13,000 \pm 400$

$\begin{array}{ll}\text { T-149B. Gyttja with rootlets } & 13,150 \pm 300\end{array}$

Depth below soil surface $115 \mathrm{~cm}$.

T-150. Brown gyttja

$12,650 \pm 300$

Depth below soil surface $105 \mathrm{~cm}$.

T-151. Gray gyttja

$11,300 \pm 300$

Depth below soil surface $95 \mathrm{~cm}$.

\section{T-152. Gray gyttja}

$10,800 \pm 300$

Depth below soil surface $75 \mathrm{~cm}$. 


\section{T-153. Brown peat moss (Sphagnum apiculatum)}

$9000 \pm 200$

Comment: T-149A pretreated only with $\mathrm{HCl}, \mathrm{T}-149 \mathrm{~B}$ and the rest of the series with $\mathrm{HCl}$ and $\mathrm{NaOH}$. The mean age of T-149A and $\mathrm{B}$ is $13,100 \pm 250 \mathrm{yr}$. (K.F.) : the levels of the dated samples correspond closely to those of the previously published pollen diagram (Faegri, 1940). T-153 is younger than the analyzed parts of the series. New pollen analyses are being undertaken; the previous tentative pollen dating is corroborated by the present one. T-149 is older than any other late-Quaternary sample known from NW Europe, but its vegetational character (Faegri, 1940) also suggests an exceptionally great age.

\section{T-107. Bringsjord terrace, Lyngdal}

$7780 \pm 190$

Marine gyttja from the lowest $5 \mathrm{~cm}$ of a bed of marine gyttja, $2.5 \mathrm{~m}$ thick, at Bringsjord near the mouth of the Lyngdal Valley in Vest-Agder $\left(58^{\circ} 12^{\prime} \mathrm{N} \mathrm{Lat}, 7^{\circ} 6^{\prime} \mathrm{E}\right.$ Long), Norway. The gyttja is exposed ca. 0 to $2.5 \mathrm{~m}$ above sealevel at the foot of a sandy and gravelly marine-delta terrace, 7 to $9 \mathrm{~m}$ above sealevel. Coll. 1957 and subm. by B. G. Andersen, University of Oslo. Comment (B.G.A.) : pollen content indicates early Atlantic age. Similar beds of marine gyttja, occurring commonly along this coast, contain fossils of Tapes (late Boreal-Atlantic or Sub-Boreal) age (Andersen, 1960).

\section{T-156. Nesheim, Lista}

$6420 \pm 160$

Shells of Ostrea edulis, Cardium edule, Littorina littorea from sand exposed in a canal, dug through a beach ridge at Nesheim, Lista, Vest-Agder $\left(58^{\circ} 8^{\prime} \mathrm{N}\right.$ Lat, $6^{\circ} 40^{\prime} \mathrm{E}$ Long), Norway. The sand bed, altitude ca. $1 \mathrm{~m}$ above sealevel, is overlain by peat layers and a gravelly beach ridge at $7 \mathrm{~m}$ above sealevel. Coll. 1957 and subm. by B. G. Andersen, University of Oslo. Comment: shells are believed to have been deposited during the early Atlantic transgression and the beach ridge during the late Atlantic-early Sub-Boreal transgression (Andersen, 1960).

\section{T-168. Tingsager, Lillesand}

$12,550 \pm 200$

Shells of Mytilus edulis, Macoma calcarea, and other genera from glaciomarine clay in a clay pit ca. $35 \mathrm{~m}$ above sealevel, at Tinsager near Lillesand, Öst-Agder $\left(58^{\circ} 16^{\prime} \mathrm{N}\right.$ Lat, $8^{\circ} 20^{\prime} \mathrm{E}$ Long), Norway. Coll. 1959 and subm. by B. G. Andersen, University of Oslo. Comment (B.G.A.) : clay contained many erratics and was probably deposited near the ice front approximately at the Kristiansand glacial substage, probably of Alleröd or Older Dryas age (Andersen, 1960).

\section{Limestone series, near Larvik}

Stromatolitic limestone from the small island of Malmö in Tjölling near Larvik $\left(59^{\circ} 1^{\prime} \mathrm{N}\right.$ Lat, $10^{\circ} 6^{\prime} \mathrm{E}$ Long), Norway. Identical with T.92 (Trondheim I) and collected at the same locality $\left(59^{\circ} 1^{\prime} \mathrm{N}\right.$ Lat, $10^{\circ} 6^{\prime} \mathrm{E}$ Long). T-146 has been chosen as our reference standard for $\mathrm{C}^{13}$ content of carbonate. Coll. 1958 and subm. by O. A. Höeg, University of Oslo.

\section{T-146. Stromatolitic limestone II}

T-160. Stromatolitic limestone III

Comment: at the request of the submitter, these $\mathrm{C}^{14}$ measurements were made 
with greater accuracy than before. A preliminary dating by the ioniumuranium method was carried out on T-146. The Ionium was measured in our laboratory by counting radon in a $\mathrm{CO}_{2}$ gas-counter, and the Uranium was measured in a fluorimetric analysis by J. Chervet, Centre d'Etudes Nucléaires de Fontenay-aux-Roses, France. Result: Ionium: 1.4 counts $/ \mathrm{min}$ per $\mathrm{g}$ of carbonate; Uranium: 2.5 counts $/ \mathrm{min}$ per g of carbonate $(3.5 \mathrm{ppm})$. About $65 \%$ of the equilibrium value seems to have been attained by the Ionium in this sample, which corresponds to an age of about $100,000 \mathrm{yr}$.

\section{ARCHAEOLOGIC SAMPLES.}

\section{A. Norway}

1. Settlement Sites

\section{Steigen series, Nordland}

Charcoal from a site at Bö, Steigen, Engelöy, Nordland $\left(67^{\circ} 58^{\prime} \mathrm{N}\right.$ Lat, $14^{\circ} 58^{\prime}$ E Long), Norway. Samples collected from different hearths within the site, which was a dwellingplace with many houses of military character connected to a chief settlement. Coll. 1957 and subm. by H. E. Lund, The Museum of Stavanger.
T-44. Steigen, hearth II
$1900 \pm 100$
T-45. Steigen, hearth III
$1580 \pm 380$
T-48. Steigen, hearth IV
$1600 \pm 360$

Comment: dated in 1957. Pretreatment: $0.25 \mathrm{M} \mathrm{HCl}, 0.25 \mathrm{M} \mathrm{NaOH}$. (H.E.L.) : the dwelling place can hardly be older than the younger Roman age, A.D. 200400 (Lund, 1955), which fits well with the $\mathrm{C}^{14}$ dating.

\section{T-127. Naustnuten, Telemark}

$3410 \pm 140$

Charcoal from a site at the outlet of Naustvatn, altitude $939 \mathrm{~m}$ above sealevel, Naustnuten, Songa, Vinje, Telemark ( $59^{\circ} 50^{\prime} \mathrm{N}$ Lat, $7^{\circ} 30^{\prime} \mathrm{E}$ Long), Norway. Found under a soil- and turf layer, 3 to $10 \mathrm{~cm}$ thick, accompanied by many flint tools and some rock crystals (Hagen, 1956-1957). Coll. 1958 and subm. by A. Hagen, The University Museum of National Antiquities, Oslo. Comment: pretreatment: $0.25 \mathrm{M} \mathrm{HCl}, 0.25 \mathrm{M} \mathrm{NaOH}$. (A.H.) : expected date: 1800-2500 B.c. The $\mathrm{C}^{14}$ date is too young for the culture, but the charcoal may have belonged to later visitors at the site.

\section{T-128. Dragar-osen II, Telemark $\quad 3970 \pm 100$}

Charcoal from a site in Dragarosen at Björnsbuvatn, Songa, Vinje, Telemark $\left(59^{\circ} 30^{\prime} \mathrm{N}\right.$ Lat, $7^{\circ} 30^{\prime} \mathrm{E}$ Long), Norway. The site, rich in stone artifacts (Hagen, 1956-1957), is $10 \mathrm{~m}$ from the lake shore, altitude $950 \mathrm{~m}$ above sealevel, and was covered by a layer of humified Calluna peat, 3 to $10 \mathrm{~cm}$ thick. Coll. 1958 and subm. by A. Hagen, The University of National Antiquities, Oslo. Comment: pretreatment: $0.25 \mathrm{M} \mathrm{HCl}, 0.25 \mathrm{M} \mathrm{NaOH}$. (A.H.) : expected age: Neolithic, younger than 2500 B.c.

\section{T-129. Vesle Beruosen I, Telemark}

$$
4130 \pm 120
$$

Charcoal from hearth in a site in Vesle Beruosen at Beruvatn, Vinje, Telemark $\left(59^{\circ} 50^{\prime} \mathrm{N}\right.$ Lat, $7^{\circ} 30^{\prime} \mathrm{E}$ Long $)$, Norway, altitude $950 \mathrm{~m}$. Accompanied by stone artifacts (Hagen, 1956-1957) and covered by Calluna peat 
and modern low vegetation. Coll. 1958 and subm. by A. Hagen, The University Museum of National Antiquities, Oslo. Comment (A.H.) : expected date: Neolithic, about 1500-2000 B.c.

T-130. Vesle Beruosen II, Telemark

$6100 \pm 140$

Charcoal from a site near mouth of river at Store Beruvatn, Songa, Vinje, Telemark ( $59^{\circ} 50^{\prime} \mathrm{N}$ Lat, $7^{\circ} 30^{\prime} \mathrm{E}$ Long), Norway, altitude $940 \mathrm{~m}$. Accompanied by worked flakes and other stone artifacts (Hagen, 1956-1957), overlain by Calluna peat. Coll. 1958 and subm. by A. Hagen, The University Museum of National Antiquities, Oslo. Comment: pretreatment: $0.25 \mathrm{M} \mathrm{HCl}$, $0.25 \mathrm{M}$ NaOH. (A.H.) : expected date: 2000-2500 B.c. The $\mathrm{C}^{14}$ age seems very great, but as the finds cannot be archaeologically dated with exactitude, it may be correct.

\section{T-131. Vrålsbu II, Telemark}

$6860 \pm 140$

Charcoal from a site at outlet of lake Vrålsbuvatn, Songa, Vinje, Telemark ( $59^{\circ} 50^{\prime} \mathrm{N}$ Lat, $7^{\circ} 30^{\prime} \mathrm{E}$ Long), Norway, altitude $950 \mathrm{~m}$ (near lake level). Sample from the deepest layer, accompanied by flint and quartz implements (Hagen, 1956-1957). Coll. 1958 and subm. by A. Hagen, The University Museum of National Antiquities, Oslo. Comment: pretreatment: 0.25 M HCl, 0.25 M NaOH. (A.H.) : expected date: Neolithic. The $\mathrm{C}^{14}$ result, though unexpectedly old, is not impossible, as the finds are among the most archaic in the Songa district.

\section{T-132. Kaupang, Vestfold}

$1120 \pm 90$

Wood poles from a wet layer of gyttja and sand, altitude ca. $1.90 \mathrm{~m}$ above sealevel, Kaupang, Tjölling, Vestfold $\left(59^{\circ} 2^{\prime} \mathrm{N}\right.$ Lat, $10^{\circ} 65^{\prime} \mathrm{E}$ Long), Norway. The poles may have been used to moor boats; a jetty of stones was found higher up on the shore. Coll. 1958 and subm. by Ch. Blindheim, The University Museum of National Antiquities, Oslo. Comment: pretreatment: $0.25 \mathrm{M} \mathrm{HCl}, 0.25 \mathrm{M} \mathrm{NaOH}$. (C.B.) : expected date: A.D. 800-900. A Rhenish potsherd, dating from the earlier part of the Viking Age, was found close by the poles. The whole complex belongs to a marketplace (Skiringssal), mentioned by Othere to King Alfred the Great. Thus documentary and archaeologic evidence agree that this marketplace must have been flourishing in the 9th and early 10th centuries.

\section{T-133. Rognlien, Telemark}

$4700 \pm 120$

Charcoal from Rognlien, Eidanger, Telemark $\left(59^{\circ} 4^{\prime} \mathrm{N}\right.$ Lat, $9^{\circ} 38^{\prime} \mathbf{E}$ Long), Norway. Sample found in a habitation layer, $20 \mathrm{~cm}$ thick, in a site, altitude $21 \mathrm{~m}$ above sealevel. Coll. 1958 and subm. by A. S. Ingstad, The University Museum of National Antiquities, Oslo. Comment: pretreatment: $0.25 \mathrm{M} \mathrm{HCl}, 0.25 \mathrm{M} \mathrm{NaOH}$. (A.S.I.) : expected date: middle Neolithic, about 1900 B.C. The $\mathrm{C}^{14}$ date and the archaeologic date disagree, and none of the implements found on the site can be so old. Moreover, the place is situated close to an ancient shoreline, which for geologic reasons cannot be as old as the radiocarbon dating indicates.

T-134. Sletta, Östfold

$2220 \pm 110$

Charcoal from a site in Sletta, Kråkeröy, Östfold $\left(59^{\circ} 12^{\prime} \mathrm{N}\right.$ Lat, $10^{\circ} 55^{\prime}$

E Long), Norway. Sample found in a hearth which was covered by a layer 
great. Pretreatment: $0.25 \mathrm{M} \mathrm{HCl}, 0.25 \mathrm{M} \mathrm{NaOH}$. (K.R.M.) : the connecting of turf and gravel, 15 to $20 \mathrm{~cm}$ thick. Coll. 1958 and subm. by E. Johansen, The University Museum of National Antiquities, Oslo. Comment: pretreatment: $0.25 \mathrm{M} \mathrm{HCl}, 0.25 \mathrm{M} \mathrm{NaOH}$. (E.J.) : expected date: Neolithic, about 4000 в.P. The $\mathrm{C}^{14}$ date and the archaeologic date disagree, and it is unlikely that any Stone Age finds can be as late as the radiocarbon dating indicates.

\section{T-136. Rödsmyra, Östfold}

$2220 \pm 110$

Charcoal from a site in Rödsmyra, Kråkeröy, Östfold $\left(59^{\circ} 12^{\prime} \mathrm{N}\right.$ Lat, $10^{\circ} 55^{\prime}$ E Long), Norway. Sample collected from a hearth covered by a thin layer of gravel. The subsoil consists of sand and gravel. Coll. 1958 and subm. by E. Johansen, The University Museum of National Antiquities, Oslo. Comment: pretreatment: $0.25 \mathrm{M} \mathrm{HCl}, 0.25 \mathrm{M} \mathrm{NaOH}$. (E.J.) : expected date: Neolithic, ca. 4000 B.P. The $\mathrm{C}^{14}$ date and the archaeologic date disagree (Johansen, 1957), and it is unlikely that any Stone Age finds can be as late as the radiocarbon dating indicates.

\section{Nesvikja II series, Hordaland}

Charcoal from an open Neolithic Age habitation site called Nesvikja II, Hummelsund, Hordaland $\left(60^{\circ} 10^{\prime} \mathrm{N}\right.$ Lat, $5^{\circ} 40^{\prime} \mathrm{E}$ Long), Norway. T-162 was collected within the main settlement at a depth of $15 \mathrm{~cm}$ in the culture layer, which is $20 \mathrm{~cm}$ deep. T-163 was collected in the outskirts of the settlement, about $40 \mathrm{~cm}$ under a peat layer. Some flint and quartz was found with the charcoal. Coll. 1958 and subm. by E. Bakka, Historical Museum, University of Bergen.

\section{T-162. Nesvikja II, main settlement}

T-163. Nesvikja II, under peat

$3670 \pm 130$

$3860 \pm 140$

Comment (E.B.) : expected age: $2000 \pm 200$ в.c. (later part of middle $\mathrm{Neo}$ lithic period), which agrees well with the $\mathrm{C}^{14}$ measurement. The stone industry depended first of all on a very fine-grained quartzite, to a lesser degree on flint. Blades made from cylindrical cores are prominent. Artifacts include: a number of simple tanged arrowheads; scrapers; knives with chipped back, made from blades; some reworked flakes; a typical stone adze, made of a flake; a greenstone adze, well polished, of "Vespestad" type; one piece of polished slate; hammerstones; one flint flake, possibly chipped from a Neolithic thick-butted flint axe (Fett, 1958). Closely related sites are Garnes (Brögger, 1913) and Nappen (Böe, 1921-1922, p. 30), both in Hordaland. The stone industry is also related to that found in southern Scandinavian sites of the Pitted-ware culture (Becker, 1950).

\section{Various Archaeologic Samples}

\section{T-99. Wooden trackway, Nord-Tröndelag $\quad 800 \pm 90$}

Pine wood from a wooden trackway found at $150 \mathrm{~cm}$ depth in the bog Setnanmyra, Lånke, Nord-Tröndelag ( $63^{\circ} 24^{\prime} \mathrm{N}$ Lat, $10^{\circ} 61^{\prime} \mathrm{E}$ Long), Norway. The trackway consists of two longitudinal stringers $0.6 \mathrm{~m}$ apart, resting on sleepers. Coll. 1957 and subm. by K. R. Möllenhus, Vidensskapselskapets Oldsaksamling, Trondheim. Comment: the sampled log had rotted in the outermost layers. Because of resulting difficulties in counting the tree rings, a systematic error is included in the result, which may be as much as $50 \mathrm{yr}$ too 
road between Selbu and the Trondheimsfjord runs near the trackway. It may be supposed that all the dated trackways (T-99, T-100, and T-101) are parts of a medieval road through Lånke and Selbu. Their construction is similar in many respects (Marstrander, 1952; Kulturhistorisk Leksikon, 1957). These are the first wooden trackways of this type in Norway to have been dated by the radiocarbon method.

T-100. Wooden trackway, Sör-Tröndelag

$800 \pm 100$

Pine wood from a wooden trackway found at $80 \mathrm{~cm}$ depth in a bog at Tömra, Selbu, Sör-Tröndelag ( $63^{\circ} 17^{\prime} \mathrm{N}$ Lat, $10^{\circ} 65^{\prime} \mathrm{E}$ Long), Norway. In construction the trackway is very similar to T-99 but consists of several longitudinal stringers made of split trunks, all lying with the plane side up, near the present main road (Möllenhus, 1953). Coll. 1957 and subm. by K. R. Möllenhus, Videnskapsselskapets Oldsaksamling, Trondheim. Comment: for the same reason as for T-99, T-10l may be too old by as much as $50 \mathrm{yr}$.

\section{T-101. Wooden trackway, Sör-Tröndelag}

$610 \pm 90$

Pine wood from a wooden trackway found at $60 \mathrm{~cm}$ depth in a bog in Eidem, Selbu, Sör-Tröndelag ( $63^{\circ} 15^{\prime} \mathrm{N}$ Lat, $10^{\circ} 65^{\prime} \mathrm{E}$ Long), Norway. The construction is similar to T-99 and T-100, and the trackway was found near the present main road (Möllenhus, 1958). Coll. 1957 and subm. by K. R. Möllenhus, Videnskapsselskapets Oldsaksamling, Trondheim. Comment: pretreatment: $0.25 \mathrm{M} \mathrm{HCl}, 0.25 \mathrm{M} \mathrm{NaOH}$.

\section{T-137. Ula, Östfold}

$2010 \pm 110$

Charcoal from Ula, Glemmen, Östfold ( $59^{\circ} 13^{\prime} \mathrm{N}$ Lat, $10^{\circ} 55^{\prime} \mathrm{E}$ Long), Norway. Found in a grave accompanied by a small iron sickle and some burned bones, covered by a flat stone. Coll. 1957 and subm. by K. VibeMüller, The University Museum of National Antiquities, Oslo. Comment: pretreatment: $0.25 \mathrm{M} \mathrm{HCl}, 0.25 \mathrm{M} \mathrm{NaOH}$. (K.V.-M.) : expected date: early Iron Age, lst century A.D.

\section{Hvaler church series, Östfold}

Wood (T-164) from roof construction of the old Hvaler church and charcoal (T-165) from a fireplace in a house excavated under the church foundation, Hvaler, Östfold $\left(59^{\circ} 2^{\prime} \mathrm{N}\right.$ Lat, $11^{\circ} 2^{\prime} \mathrm{E}$ Long), Norway. The fireplace was covered by 20 to $25 \mathrm{~cm}$ of gravel. Coll. 1954 by E. Johansen, The University Museum of National Antiquities, and A. Madsen, inspector of Hvaler church.

\section{T-164. Wood from Hvaler church}

$$
950 \pm 80
$$

T-165. Charcoal below church foundation

$$
1980 \pm 100
$$

Comment (E.J.) : the dating of T-165 is of great interest because it refers to the first house found under a mediaeval church in Norway. Probably the house was a pre-Christian religious center, but it can not be dated archaeologically. If the dating is correct, we have evidence of a shrine in continuous use from about the time of Christ to the present day.

\section{ReFERENCES}

Andersen, B. G., 1960, Sörlandet i sen- og postglacial tid: Norges geol. undersökelse Småskr. no. $210,141 \mathrm{p}$.

Becker, C. J., 1950, Den grubekeramiske kultur i Danmark: Årböger for nordisk oldkyndighet og historie [with references], p. 153-263. 
Björlykke, K. O., 1908, Jaederens geologi: Norges geol. undersökelse no. 48, 160 p.

Brögger, A. W., 1913, Stenalderbostedet ved Garnes: Bergens Mus. Aarb. 1913, no. 2, $27 \mathrm{p}$.

Brögger, W. C., 1901, Om de senglaciale og postglaciale nivåforandringer i Christianiafeltet: Norges geol. undersökelse no. 31, $732 \mathrm{p}$.

Böe, J., 1921-1922, Bergens Museums tilvekst av oldsaker 1922: Bergens Mus. Aarb. 19211922, hist. antikv. rekke no. 2,77 p.

Cockroft, A. L., and Curran, S. C., 195il, The elimination of end effect in counters: Rev. Sci. Instruments, v. 22 , no. 1 , p. $37-42$.

Craig, Harmon, 1953, The geochemistry of the stable carbon isotopes: Geochim. et. Cosmochim. Acta, v. 3, p. 53-92

1954, Carbon 13 in plants and the relationships between Carbon 13 and Carbon 14 variations in nature: Jour. Geology, v. 62 , p. 115-149.

Fett, P., 1958, Oldsaksamlingens tilvekst 1958: Univ. Bergen Ārb. 1958, hist. antikv. rekke no. 6, p. 17-22.

Faegri, Knut, 1936, Quartärgeologische Untersuchungen im westlichen Norwegen; I, Ueber zwei präboreale Klimaschwankungen im südwestlichsten Teil: Bergens Mus. Aarb. 1935, naturv. rekke, hefte 2, no. 8, $40 \mathrm{p}$.

1940, Quartärgeologische Untersuchungen im westlichen Norwegen; II, Zur spätquartären Geschichte Jaerens: Bergens Mus. Aarb. 1939-1940, naturv. rekke, hefte 2, no. 7, $202 \mathrm{p}$.

1-4, p. 61-76, On the peri-glacial flora of Jaeren: Norsk geog. tidsskr., v. 14, hefte

Hagen, A., 1956-1957, Vassdragsreguleringer og höyfjellsarkeologi: Univ. Oldsaksamling Årb. [Oslo], p. 98-150.

Holmboe, J., 1903, Planterester i norske torvmyrer: Christiania Vidensk. Selsk. Skr. 1, naturv. rekke no. $2,227 \mathrm{p}$.

Holtedahl, Hans, 1956, On the Norwegian continental terrace, primarily outside MöreRomsdal; its geomorphology and sediments, with contributions on the Quaternary geology of the adjacent land and on the bottom deposits of the Norwegian sea: Univ. Bergen Ārb. 1955, naturv. rekke no. 14, 209 p.

Holtedahl, Olaf, 1953, Norges geologi, v, 1 and 2: Norges geol. undersökelse no. 164, $11118 \mathrm{p}$.

Horn, Gunnar, and Isachsen, Fridtjor, 1942. Et kullfund i Skagerrakmorenen på Jaeren: Norsk geol. tidsskr., v. 22, p. 15-46 [English summary].

Johansen, E., 1954-1955, Fortidsfunn og fremtidsvyer: Östfoldarv [Ārb. for Mus. og Hist. lag i Östfold], v. 3, p. 87-103.

- 1957, Kråkeröys geologi og eldste historie: Kråkeröy, Halden, 105 p.

Kolderup, C. F., 1908, Bergensfeltet og tilsötende trakter i senglacial og postglacial tid: Bergens Mus. Aarb. 1907, no. 14, p. 1-268 [German summary, p. 240-256].

Kulturhistorisk Leksikon, 1957, Bro: Kulturhistorisk leksikon for nordisk middelalder [Oslo], v. 2 , p. 242.

Lund, H. E., 1955, Hålöygske hövdingseter fra jernalderen: Stavanger Mus. Årb. 1955, p. $101-107$.

Lundqvist, Jan, 1957, C ${ }^{14}$-dateringar av rekurrensytor i Värmland: Sveriges geol. undersökning, ser. C, no. 554; Ärsb. 51, no. 5, 22 p. [English summary].

Marstrander, Sverre, 1952, Befaring av veianlegg i Setnanmyrene, Lảnke, Sör-Tröndelag: Report in Vidensk. Selsk. Oldsaksamling [Trondheim], topog. arkiv, 2 p.

Marthinussen, Marius, 1945, Yngre postglaciale nivåer på Varangerhalvöya: Norsk geol. tidsskr., v. 25 , p. $230-265$.

Möllenhus, Kr. R., 1953, Undersökelse av en trebrolegning på Tömra, Selbu, NordTröndelag: Report in Vidensk. Selsk. Oldsaksamling [Trondheim], topog. arkiv, $3 \mathrm{p}$. 1958, Brolegning på Eidem, Selbu, Nord-Tröndelag: Report in Vidensk. Selsk. Oldsaksamling [Trondheim], topog. arkiv, 1 p.

Nydal, R., 1959, Trondheim natural radiocarbon measurements I: Am. Jour. Scr. Radioc. Supp., v. 1, p. 76-80.

Nydal, R., and Sigmond, R. S., 1957, Radiocarbon dating in Trondheim: Appl. Sci. Res., sec. B, v. 6, p. $393-400$

Öyen, P. A., 1905, Nygårdsprofilet på Karmöen: Christiania Vidensk. Selsk. Forh. 8, 15 p.

Reath, C. H., Sevold, B. J., and Pederson, C. N., 1951, A multiple-anode anticoincidence ring counter: Rev. Sci. Instruments, v. 22, p. 461-463.

Undås, Isak, 1942, Fossilfunnet i Blområg: Naturen, Ārg. 66, p. 97-107. 